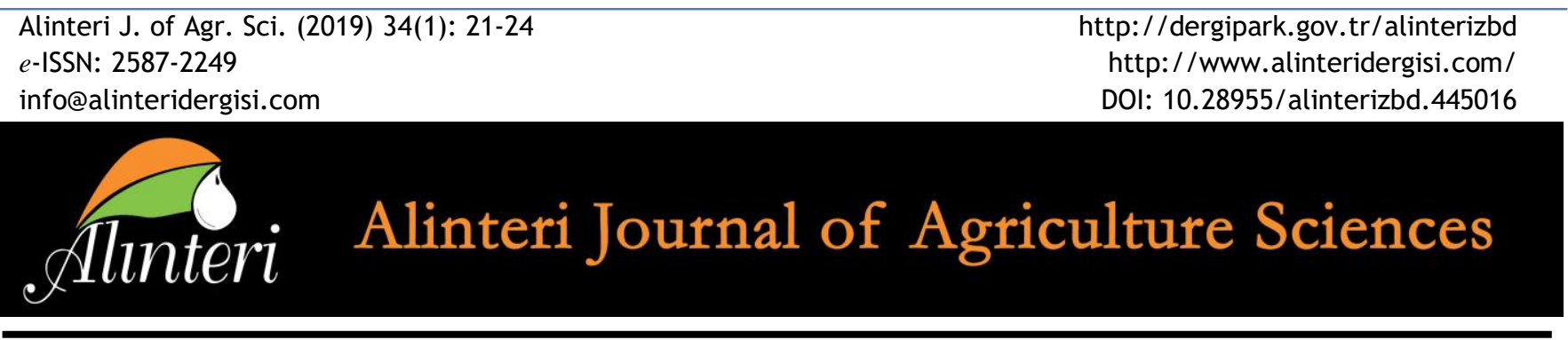

RESEARCH ARTICLE

\title{
The Evaluation of the Antibacterial Activity of Vetiveria zizanioides (L.) Nash Grown in Giresun, Turkey
}

\section{Derya Efe*}

Giresun University, Espiye Vocational School, Giresun/Turkey

\author{
ARTICLE INFO \\ Article History: \\ Received: 18.07 .2018 \\ Accepted: 17.12.2018 \\ Available Online: 20.03.2019 \\ Keywords: \\ Antibacterial activity \\ Essential oil \\ Vetivera zizanioides
}

\begin{abstract}
A B S T RACT
Medicinal and aromatic plants have been known since ancient times due to their aromatic and therapeutic properties. These plants can be used as crude, or in some cases their essential oils or extracts with different solvents. Essential oils with different biological activities are widely used in food, medicinal and cosmetic industries. The essential oil of Vetiveria zizanioides (L.) Nash is one of the most prevalent essential oils. The plant is a perennial, dense, bunch-type grass with stiff stem and has a significantly deep and strong root system. It has many biological activities as antimicrobial, antifungal, antiviral, anticarconogenic, etc. activities. In this study, the antibacterial potential of essential oil obtained from vetiver grass grown in Giresun was investigated for the first time against for pathogen microorganisms (Enterobacter cloacae (ATCC 13047), Enterococcus faecalis (ATCC 29212), Escherichia coli (ATCC 25922) and Proteus vulgaris (ATCC 13315). Considering antibacterial activity, the minimal inhibitory concentration (MIC) value for E. cloacae, E. faecalis, E. coli and P. vulgaris was 15.63, 31.25, 15.63 and $15.63 \mu \mathrm{g} / \mathrm{ml}$, respectively. According to the results of this study, it is revealed that the essential oil of vetiver has significant antibacterial activity.
\end{abstract}

Please cite this paper as follows:

Efe, D. (2019). The Evaluation of the Antibacterial Activity of Vetiveria zizanioides (L.) Nash Grown in Giresun, Turkey. Alinteri Journal of Agriculture Sciences, 34(1): 21-24. doi: 10.28955/alinterizbd.445016

\section{Introduction}

Pathogenic microorganisms cause many diseases with different mechanism after entering the body. The substances used for the treatment of the pathogens are either natural or synthetic antibiotics. However, as well as the therapeutic properties, the synthetic antibiotics have adverse side effects on human health (Wang et al. 2006; Ayhan and Taș 2013; Tekiner 2016). Due to the side effects of synthetic antibiotics, scientists have begun to search alternative natural components without side effects. In this regard, medical and aromatic plants used by local people in the treatment of many bacterial diseases attracted the attention of the scientific world. Medical and aromatic plants can be used as crude. Besides, they can be used as essential oils or modified medication formulations and extracts prepared with various solvents (Adorjan and Buchbauer 2010).
Vetiveria zizanioides (L.) Nash study is a plant growing in Southern Asia, Burmese, Ceylon Island, Bangladesh and tropical Africa and used in these countries as an alternative medicine. V. zizanioides called as 'vetiver' belongs to the Poaceae family (Pareek and Kumar 2013; Soni and Dahiya 2015). This plant is perennial plant and has a highly durable reed-like body that is clustered in dense bundles and a strong root system that can descend quite deep (Cındık 2012). Particularly, the roots of the plants have been used since ancient times due to its fragrant nature. The roots of this plants can reach a length of about three meters and contains a high amount of essential oil which has important medical and aromatic properties (Chomchalow 2001; Soni and Dahiya 2015). The essential oil obtained from the roots of the vetiver is used for the treatment of depression, nervous tension, anxiety disorders, sleep disorders, sexual dysfunction (Chomchalow 2001). It also has a commercial importance since it is used as

\footnotetext{
* Corresponding author

E-mail address: derya.yanmis@giresun.edu.tr
} 
a stabilizing oil in perfume production due to its slow evaporation feature (Sellar 2005; Pareek and Kumar 2013). The main active ingredients of vetiver oil are vetiverol, vetivone, khusiyone, various terpenes, sesquiterpenoids and khusimol which are fingerprints of the vetiver. Due to its different active ingredients, this oil has biological characteristics such as being antimicrobial, antiviral and antioxidant (Soni and Dahiya 2015). However, as in all medical and aromatic plants, the vetiver may have different active ingredients with different proportions depending upon the geographical region and climate characteristics in which it grows. Therefore, the antibacterial effect of the essential oil obtained from Vetiveria zizanioides (L.) Nash, which was grown for the first time in the Black Sea Region (Tirebolu/Giresun) of Turkey. The antibacterial activity of the essential oil was evaluated against the pathogen bacteria members (Enterobacter cloacae, Enterococcus faecalis, Escherichia coli and Proteus vulgaris) of the Enterobacteriaceae family.

\section{Materials and Methods}

\section{Supply of the Plant Material and Extraction of the Essential Oil}

Vetiveria zizanioides (L.) Nash was supplied from the field of Il-Ca Herbal Products Research-Development Production Company in April 2017. The field of this company was located in Tirebolu/Giresun in the Black Sea Region (40.979955, 38.783850). Two- years old vetiver roots were used to obtain essential oil. The roots were thoroughly washed with tap water and then pure water. Afterwards, they were dried in the shade. After grinding the dried roots, $50 \mathrm{gr}$ were taken and subjected to hydrodistillation for 24 hours in clevenger apparatus (Thermal Laboratory Equipment, Turkey). The acquired essential oil was dried in a lyophilizer. The dried essential oil was then dissolved in $10 \%$ dimethyl sulfoxide (DMSO) to a final concentration of $500 \mu \mathrm{g} / \mathrm{ml}$ and stored in $+4^{\circ} \mathrm{C}$ for further use.

\section{Bacterial Isolates}

The studied bacteria [Enterobacter cloacae (ATCC 13047), Enterococcus faecalis (ATCC 29212), Escherichia coli (ATCC 25922) and Proteus vulgaris (ATCC 13315)] were obtained from the University of Recep Tayyip Erdoğan, Rize, Department of Biology, Bacteria Culture Collection of the Molecular Biology Laboratory.

\section{Antibacterial Tests}

\section{Testing the Effectiveness by Disk Diffusion Method}

Serial dilutions of essential oil were obtained with $10 \%$ DMSO. The prepared concentrations of the essential oils were $7.81,15.62,31.25,62.5,125,250$ and $500 \mu \mathrm{g} / \mathrm{ml}$. The antibacterial test was performed via the disk diffusion method. The bacterial strains were grown in tryptic soy broth (TSB, Merck) and then each bacterial solutions containing a cell suspension of 108 cells/ml was spread on Tryptic soy agar (TSA,
Merck) with a sterile swab (Janssen et al. 1987; Murray et al. 2003; Gormez et al. 2013). Each 6-mm standard disc was filled with $10 \mu \mathrm{l}$ of each concentration and placed on agar inoculated with the pathogenic microorganism. As a negative control, $10 \%$ DMSO was used. Meropenem (10 $\mu \mathrm{g})$, vancomycine $(30 \mu \mathrm{g})$, ampicilline $(10 \mu \mathrm{g})$ and amoxacillin $(30 \mu \mathrm{g})$ were used as positive controls. All the experimental groups were incubated at $37{ }^{\circ} \mathrm{C}$ for 24 hours. At the end of the specified period, transparent inhibition zone diameters around the standard discs were measured and recorded (Gormez et al. 2015).

\section{Determination of Minimal Inhibitory Concentrations (MIC) of Essential Oil}

Minimal inhibition concentration (MIC) was determined by microwell dilution method. Bacterial cultures grown in liquid cultures for 12 hours were adjusted to concentrations of 108 cells $/ \mathrm{ml}$ by using 0.5 McFarland standard turbidimetry. The essential oil was prepared with $10 \%$ DMSO as seven concentrations $(7.8115 .6231 .25,62.5,125,250$ and 500 $\mu \mathrm{g} / \mathrm{ml})$. The liquid medium $(95 \mu \mathrm{l})$ and $5 \mu \mathrm{l}$ of the bacterial solutions were added to each well of the ELISA plates. The final volume was then adjusted to $200 \mu$ by adding essential oil of different concentrations. DMSO was added to the last well as the negative control. The prepared plates were incubated at $37^{\circ} \mathrm{C}$ for 24 hours in a shaking incubator. All experiments were repeated three times. The minimum inhibitory concentration value was determined by measuring the turbidity of bacteria with a microplate reader at a wavelength of $600 \mathrm{~nm}$ (Zgoda and Porter 2001; Gormez et al. 2013).

\section{Results and Discussion}

Members of the Enterobacteriaceae family are Gramnegative bacteria which are important components of human and animal intestinal microflora (Doğan et al. 1996; Torlak 2011). The opportunist and pathogenic members of these bacteria cause many serious infections such as septicemia, urinary system infections, pneumonia, cholecystitis, cholangitis, peritonitis, wound infections, meningitis and gastroenteritis (Foxman 2002). Enterobacter cloacae (ATCC13047), Enterococcus faecalis (ATCC29212), Escherichia coli (ATCC25922) and Proteus vulgaris (ATCC13315) used in this study are these causing serious diseases as mentioned above. For the treatment of these diseases antibiotics worth millions of dollars are consumed every year. Hence, it is vital to identify natural substances having the potential to be used against these bacteria. Vetiver essential oil is rich in various chemicals such as benzoic acid, furfural, vetivene, vetineil vetinate, terpinene-4-ol, 5-epiprezizane, khusimene, amuurolene, khusimon, kalakoren, B-humulene, a-longipinen, $\mathrm{d}$-selinene, d-cadinene, valencene, kalaren-gurjunen, a-amorf en, epizizanal, 3-epizizanol, khusimol, iso-khusimol, valerenol, B-vetivone and vetivazulene (Kokate 1991; Pareek and Kumar 2013).

The odor and chemical composition of an essential oil may vary according to the geography, climate and conditions in which it grows (soil type, altitude, water amount it can find) and to the season (e.g. before the flowering period, after the 
flowering period) and even to the period of the day in which it is harvested (Margaris et al. 1982; Pengelly 2004; Putiyanan et al. 2005; Andrade et al. 2011). Due to the reasons mentioned above, a species of plant can produce different essential oils or the essential contents can differ, thus, the therapeutic traits of the essential oil can vary. For this reason, this study was intended to investigate the antibacterial characteristics of Vetiveria zizanioides (L.) Nash growing in a different region (province of Giresun/Turkey). When the results of the study were analyzed, the MIC value for E. cloacae, E. faecalis, E. coli and $P$. vulgaris was $15.63,31.25,15.63$ and $15.63 \mu \mathrm{g} / \mathrm{ml}$, respectively (Table 1). Similar results were obtained from similar studies about antimicrobial activity of vetiver in the literature (Putiyanan et al., 2005; Barad et al. 2013; Soni and Dahiya 2015; Dahiya and Sing, 2015). According to the literature, different extracts and essential oil of the vetiver cultivars and their constituents showed antibacterial effect against Staphylococcus aureus, Escherichia coli and Pseudomonas aeruginosa, Enterococcus faecalis, Klebsiella pneumoniae, Salmonella typhi, Salmonella aureus, Acinetobacter sp., etc. at different rates.

Table 1. Antibacterial activity of the essential oil of Vetiveria zizanioides (L.) Nash

\begin{tabular}{|c|c|c|c|c|c|c|c|c|c|c|}
\hline \multirow{3}{*}{ BACTERIA } & \multicolumn{7}{|c|}{ CONCENTRATION $(\mu \mathrm{g} / \mathrm{ml})$} & \multirow[t]{3}{*}{ MIC } & \multirow{3}{*}{$\begin{array}{l}\text { NC } \\
\text { DMSO }\end{array}$} & \multirow{3}{*}{$\begin{array}{l}P C \\
\text { DD* } \\
\text { Standard antibiotic discs** }\end{array}$} \\
\hline & \multicolumn{7}{|c|}{$D^{*}$} & & & \\
\hline & 500 & 250 & 125 & 62.5 & 31.25 & 15.63 & 7.81 & & & \\
\hline $\begin{array}{l}\text { Enterebacter } \\
\text { cloacae } \\
\text { ATCC } 13047 \\
\text { Enterococcus }\end{array}$ & 19 & 16 & 14 & 13 & 10 & - & - & 15.63 & - & 22 (MEM) \\
\hline $\begin{array}{l}\text { faecalis } \\
\text { ATCC } 29212 \\
\text { Escherichia }\end{array}$ & 19 & 14 & 12 & 11 & - & - & - & 31.25 & - & 21 (VA) \\
\hline $\begin{array}{l}\text { coli ATCC } \\
25922 \\
\text { Proteus }\end{array}$ & 18 & 16 & 13 & 11 & 9 & - & - & 15.63 & - & $18(\mathrm{AMC})$ \\
\hline $\begin{array}{l}\text { vulgaris } \\
\text { ATCC } 13315\end{array}$ & 12 & 10 & 10 & 8 & - & - & - & 15.63 & - & 18 (AMP) \\
\hline
\end{tabular}

MIC, minimal inhibitory concentration, NC: Negative control, PC: Positive control, DMSO; Dimethyl sulfoxide (10\%)

${ }^{*} \mathrm{DD}$, Inhibition zone in diameter ( $\mathrm{mm} /$ sensitive strains) around the disks $(6 \mathrm{~mm})$

${ }^{* *}$ MEM: Meropenem $(10 \mu \mathrm{g})$, VA: Vancomycin $(30 \mu \mathrm{g})$, AMP: Ampiciline $(10 \mu \mathrm{g})$, AMC: Amoksacilin $(30 \mu \mathrm{g})$

The results are in accordance with the previous studies about antimicrobial activity of vetiver. It was observed that the highest inhibitory effect against the used bacteria was obtained in highest concentration $(500 \mu \mathrm{g} / \mathrm{ml})$ and that inhibition effect was lower than these obtained with antibiotics. In the literature, it has been shown that the antimicrobial activity of plant compounds can be folded double than antibiotics (Gormez et al. 2015). However, the results obtained in this study shows lower antibacterial effect than these antibiotics tested. Thus, the compounds with lower antibacterial activity may still have important role in the development of antibacterial drugs that can be used particularly for children and for the treatment of non-severe infections. Currently, only $13.6 \%$ of the used antibiotics are approved for the use by children (Andrijasevic and Walters 2010). According to the official sources, antibiotics are the most commonly used drugs for diseases of outpatient treatment in Turkey. It is estimated that at least $50 \%$ of the antibiotics used for the outpatient children are unnecessary. It is known that unnecessary use of antibiotics causes the formation of antibiotic-resistant microorganisms which can lead to more severe diseases. In addition, the country's economy may seriously affected because of unnecessary and high priced drugs (Pinar 2012; Lodha et al. 2013). The rational antibiotic use is defined as the use of the appropriate and cheap antibiotic under reasonable time and dosage according to the clinical findings and individual characteristics of patients (Yıldız et al. 2014). At this point, the use of economically produced natural products without side effects would be an appropriate approach as an alternative drug.

\section{Conclusion}

The study investigated the antibacterial properties of Vetiveria zizanioides (L.) Nash plant which was first grown in Giresun province. According to the literature, some of the studied bacterial strains can be resistant to antibiotics. Their treatments with many antibiotics are difficult, thus, the use of plant based compounds can be used which may not increase the pathogen resistance.

\section{Acknowledgements}

I would like to thank Berrin ÇAMUR, Emine ÇAMUR and all the staff of il-Ca Herbal Products Research-Development Production Company.

\section{References}

Adorjan, B., Buchbauer, G. 2010. Biological properties of essential oils: an updated review. Flavour and Fragrance Journal 25(6):407-426. 
Andrade, EHA., Alves, CN., Guimarães, EF., Carreira, LMM., Maia, JGS. 2011. Variability in essential oil composition of Piper dilatatum LC Rich. Biochemical systematics and ecology 39(4-6):669-675.

Andrijasevic, R., Walters, W. 2010. The International Organization for Migration and the international government of borders. Environment and Planning D: Society and Space 28(6):977-999.

Ayhan, G., Taş, D. 2013. Antimikrobiyal, Antiinflamatuar İlaçlar ve Biyolojik Ajanlarla Olușan Akciğer Hastalıkları. Turkiye Klinikleri Journal of Pulmonary Medicine Special Topics 6(2):40-46.

Barad, R., Atodariya, U., Bhatt, S., Patel, H., Upadhyay, S., Upadhyay, U. 2013. Antibacterial and preliminary cytotoxic activity of the roots of Vetiveria zizanioides. Int J Pharm Rev Res 3(1):23-25.

Chomchalow, N. 2001. The Utilization of Vetiver as Medicinal and Aromatic Plants with Special Reference to.

Cındık, Y. 2012. Trabzon ili Maçka ilcçesi Esiroğlu Beldesi'nde erozyona açık șev alanlarda vetiver grass (Vetiveria zizanioides (Linn.) Nash bitkisinin erozyon önleme olanaklarının araștırılması. Yüksek lisans Tezi, K.T.ü.

Doğan, HB., Sarıkaya, E., Halkman, AK. 1996. Enterobacter İdentifikasyonunda Birleștirilmiș Testler Üzerine bir Araștırma. Gıda Dergisi 21(6).

Foxman, B. 2002. Epidemiology of urinary tract infections: incidence, morbidity, and economic costs. The American journal of medicine 113(1):5-13.

Gormez, A., Bozari, S., Yanmis, D., Gulluce, M., Agar, G., Sahin, F. 2013. Antibacterial activity and chemical composition of essential oil obtained from Nepeta nuda against phytopathogenic bacteria. J Essent Oil Res 25(2):149-153.

Gormez, A., Bozari, S., Yanmis, D., Gulluce, M., Sahin, F., Agar, G. 2015. Chemical Composition and Antibacterial Activity of Essential Oils of Two Species of Lamiaceae against Phytopathogenic Bacteria. Pol J Microbiol 64(2):121-127.

Janssen, A., J. Scheffer, and A. B. Svendsen. 1987. Antimicrobial activities of essential oils. Pharmaceutisch Weekblad 9 (4):193-197.

Kokate, C. 1991. Practical Pharmacognosy 3rd ed. VPBN 3:107111.

Lodha, R., Kabra, SK., Pandey, RM.2013. Antibiotics for community-acquired pneumonia in children.

Margaris, NS., Koedam, A., Margaris, M., Vokou, D. 1982. Aromatic plants: basic and applied aspects: proceedings of an international symposium on aromatic plants, vol 7. Springer Science \& Business Media.

Murray, PR., Baron, E., Jorgensen, J., Pfaller, M., Yolken, R. 2003. Manual of clinical microbiology. . American Society for Microbiology, Washington, DC.

Pareek, A., Kumar, A. 2013. Ethnobotanical and pharmaceutical uses of Vetiveria zizanioides (Linn) Nash: a medicinal plant of Rajasthan. Int J Life Sci Pharm Sci 50:L12-L18.

Pengelly, A. 2004. The constituents of medicinal plants: an introduction to the chemistry and therapeutics of herbal medicine. CABI Pub.

Pınar, N. 2012. Ülkemizde ilaç harcamaları. Turgut Özal Tıp Merkezi Dergisi 19(1).

Putiyanan, S., Nantachit, K., Bunchoo, M., Khantava, B., CMU, CK. 2005. Pharmacognostic identification and antimicrobial activity evaluation of Vetiveria Zizanioides (L.) Nash. ex small root. CMU Journal 4(3):299.

Sellar, W. 2005. The directory of essential oils. Random House.

Soni, A., Dahiya, P. 2015. Screening of phytochemicals and antimicrobial potential of extracts of Vetiver zizanoides and Phragmites karka against clinical isolates. Int J App Pharm 7(1):22-24.

Tekiner, ïH. 2016. Gıdalardan izole edilen Enterobacterıaceae Sușlarında genișlemiș spektrumlu beta-laktamazların moleküler yöntemle araștırılması. Doktora tezi İstanbul Aydın Üniversitesi.

Torlak, E. 2011. Gıda mikrobiyolojisinde Enterobacteriaceae üyeleri için kromojenik ve florojenik besiyerleri. Türk Hijyen ve Deneysel Biyoloji Dergisi 68(1):49-58.

Wang, HH., Manuzon, M., Lehman, M, et al. 2006. Food commensal microbes as a potentially important avenue in transmitting antibiotic resistance genes. FEMS microbiology letters 254(2):226-231.

Yıldız, İ., Varkal, MA., Ünüvar, E. 2014. Günümüzde Sefaloporinler ve Antibiyotik Direnci. Çocuk Dergisi 14(1):22-27.

Zgoda, J., Porter, J. 2001. A convenient microdilution method for screening natural products against bacteria and fungi. Pharmaceutical Biology 39(3):221-225. 